\title{
Technical Audit of External Power Supply Networks of Coal Mines in the Kemerovo Region
}

\author{
Zakharov Sergei A. ${ }^{\mathrm{a}}$, Voronin Vyacheslav A. ${ }^{\mathrm{b}}$ \\ T. F. Gorbachev Kuzbass State Technical University \\ Kemerovo, Russian Federation \\ aseza1@mail.ru; ${ }^{\mathrm{b}}$ voroninva670@yandex.ru
}

\begin{abstract}
Over the past four years in the power system of the Kemerovo region there have been a number of major accidents (at the substation $220 \mathrm{kV}$ Uskatskaya, the power line $110 \mathrm{kV}$ Belovskay - Novo-Leninskay), that have led to blackouts of hazardous industrial facilities - coal mines and open pits. These events have demonstrated the vulnerability of the external power supply system of coal enterprises. The absence in most of mines in the Kemerovo region of standby power sources has led to stopping important electroreceivers, which created a threat of an accident in the coal mines themselves. The paper deals with the problem of low reliability of external power supply of coal enterprises. An overview is given of several major accidents in the power system of the Kemerovo region. The risk of total power blackout of coal mines is described. To reduce the probability of outages and increase the level of industrial safety the authors suggested conducting technical audits of external power supply networks of coal enterprises. The result of technical audits is the development of a set of measures to improve the power supply reliability of coal mines.
\end{abstract}

Keywords - accident; technical audit; coal mines; reliability of power supply; backup power supply.

\section{INTRODUCTION}

Reliability of power supply is determined by numerous factors, the most important of which are electrical scheme and redundancy [1-3]. Consumers attached to the main substation according to the scheme with low reliability (e.g. dead-end scheme) might sooner or later be de-energized. Confirmation of this is the recent event in the Crimea, when nearly two million people lost electricity as a result of damage to power lines. Such severe consequences of the accident caused by the fact that the Crimean peninsula is supplied with electric power in a dead-end mode without redundancy.

Power supply of the Kemerovo region is characterized by a higher degree of redundancy. It is carried out by its own generation and power flows from the power systems of the neighboring regions. However, the accident at the large energy facilities (500 kV substation, power plant) could lead to largescale blackouts. The peculiarity of the power system of the Kemerovo region is a large amount of hazardous production facilities - coal mines and open pits. In this regard, emergencies in power system of the Kemerovo region, accompanied by massive outages, can lead to disastrous consequences.

The objectives of the paper are to develop the methodology of technical audit of external power supply networks and the justification for its carrying out in coal mines of the Kemerovo region.

\section{MATERIALS AND METHODS}

The object of study in this paper is the coal mines of the Kemerovo region. The external power supply system of mining enterprises, which includes the electrical installations to ensure the transmission of electrical energy from the power centers to main step-down substation of the enterprise (substation, distributing arrangement and power line), is considered.

For justification of relevance of the considered subject a number of major accidents on the objects of power system of the Kemerovo region are analyzed.

\section{RESULTS AND DISCUSSION}

Coal and mining enterprises fall into the category of consumers, for which the energy consumption constraint could lead to economic, environmental and social impacts [4]. Interruptions in electricity supply of these objects may be associated not only with significant economic losses, but also with threat to the life and health of people and the environment. According to studies [7, 8], the largest number of accidents occurred in mines of the Kemerovo region which reasons are including shutdowns of electric energy. Breaks in power supply of mines create real prerequisites for the occurrence of accidents.

The mine electroreceivers include consumers of special group of the first category of reliability, and features of technological process of coal mining require emergency and technological reservation of power supply [9, 10]. «Vital» electroreceivers of mine (main fan, mine drainage pump, cage winding etc.) provide safe labor conditions and must always be in work. Also they should be part of the power supply technological/emergency reservation. Energy consumption constraint of the coal enterprises below the emergency reservation level is not allowed. In case of unscheduled shutdowns, due to damage to grid equipment of the power system or the emergency control schemes actions, power supply of hazardous production facilities may be impossible, even if there is an approved act of the emergency and technological reservation. In such cases, self-contained reserve power supplies must be employed to supply electroreceivers of emergency reservation [4-6]. However, the vast majority of coal mines in the Kemerovo region don't have self-contained 
power supplies. In this regard, any accident in the external power supply system of coal enterprises is very dangerous.

In the power system of the Kemerovo region frequently occur accidents, leading to energy consumption constraint of the coal enterprises. In recent years, the number of such accidents has increased dramatically. In 2009 year there were five outages of coal mines, in 2013 years - seventeen outages, in 2014 year - twenty one outage and in 2015 year - fifty outages [11] (Fig. 1).

According to the studies [12], the greatest number of outages is observed in electric networks of $110 \mathrm{kV}$ (Fig. 2). Outages can occur for various reasons, but most often associated with lightning surge (fig. 3). In internal power supply systems of the coal enterprises wire breakage, destruction of insulators and falling of trees on wires are the main reasons for emergency shutdowns of air-lines [13, 14].

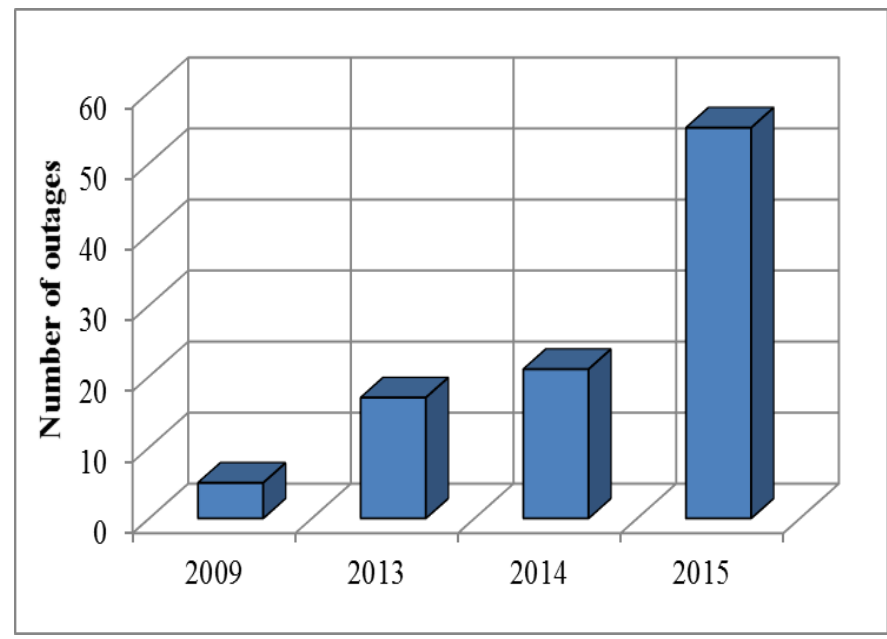

Fig. 1. Number of outages of coal mines in the Kemerovo region.

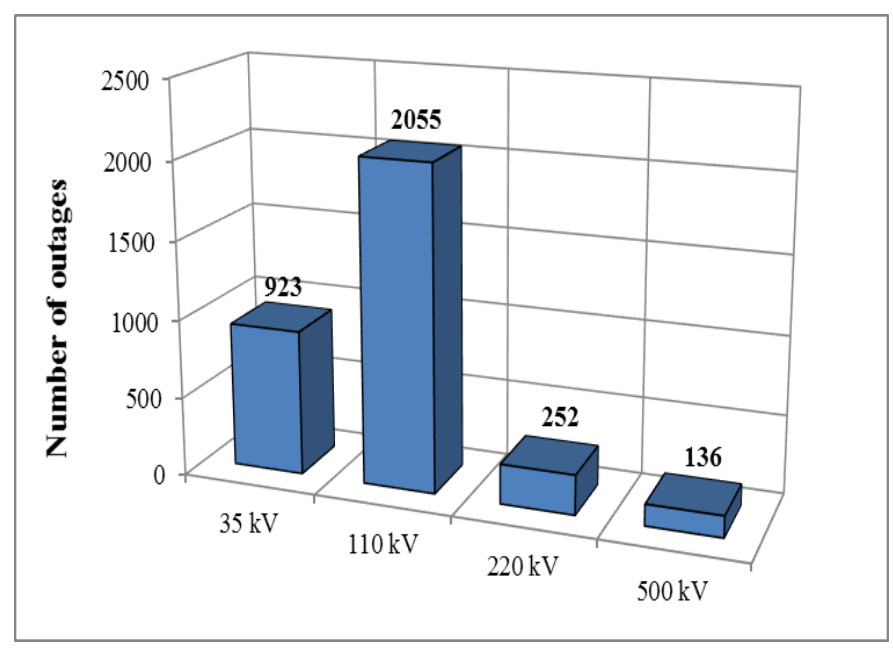

Fig. 2. Number of outages in electric networks of the Kemerovo area in 10 years by data [12].

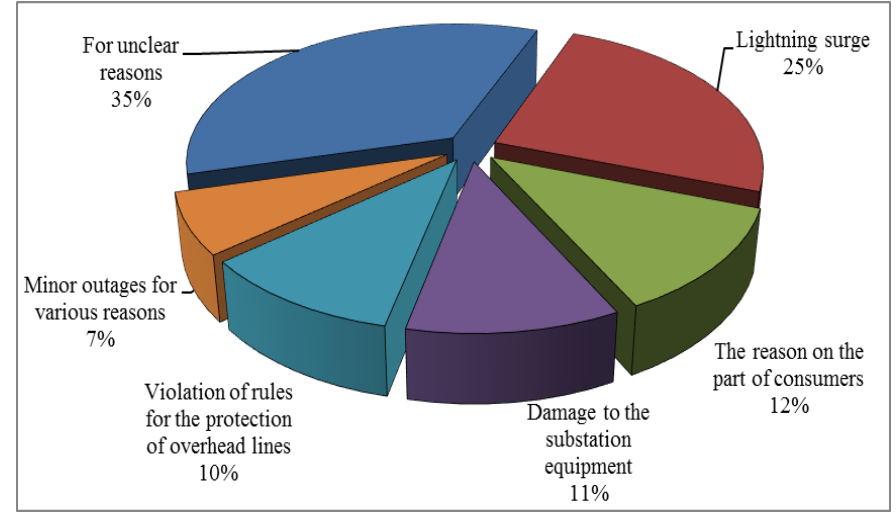

Fig. 3. The reasons of outages in electric networks of $110 \mathrm{kV}$ of the Kemerovo area in 10 years by data [12].

Over the past four years, the most serious accidents in external power supply system of coal mines in the Kemerovo region are [15]:

1. Shutdown of six mines as a result of damage to the transformer on the substation of the West Siberian metallurgical steel plant on October 19, 2012 (evacuation of 294 miners)

2. Stoppage of main fans on two mines as a result of transformer failure on the substation Polysaevsaya-3 on July $16,2013$.

3. Stoppage of main fans on the mine Osinnikovskay on September 15, 2013 as a result of external power supply interruption (evacuation of 278 miners).

The most serious accident occurred on the double-circuit transmission line $110 \mathrm{kV}$ Belovskaya - Novo-Leninskaya on January 26, 2014. Shutdown of this power line was the result of break and drop of an overhead protection cable of power line $220 \mathrm{kV}$ Belovskay GRES - Vostochnaya on the line wires of power line Belovskaya - Novo-Leninskaya (fig. 4). The accident led to a shutdown of seven coal enterprises and the evacuation of more than a thousand miners. Earlier also there was a major accident on this line. On May 28, 2002 due to the hurricane struck the power transmission pole, as a result four coal mines were left without electricity $[16,17]$.

The last major accident occurred on the substation $220 \mathrm{kV}$ Uskatskaya caused by fire on the autotransformer AT-2 (fig. 5) on April 4, 2015. To ensure the safety of fire extinguishing, AT-1 had also been shutdown. The accident led to a total blackout of substation Uskatskay. As a result nine $110 \mathrm{kV}$ substations and seven $35 \mathrm{kV}$ substation were de-energized, among which there are substations of hazardous production facilities. Two coal mines lost power supply and had to evacuate the miners. After six hours electricity supply to consumers was partially restored. During the postemergency conditions, consumers are partially supplied from the substation Severniy-Maganak though substation Stepnaya and $110 \mathrm{kV}$ switchgear of substation Uskatskaya (fig. 5). Then substations of coal enterprises were allowed to turn on the feeders, which supplied main fan and mine drainage pump. 


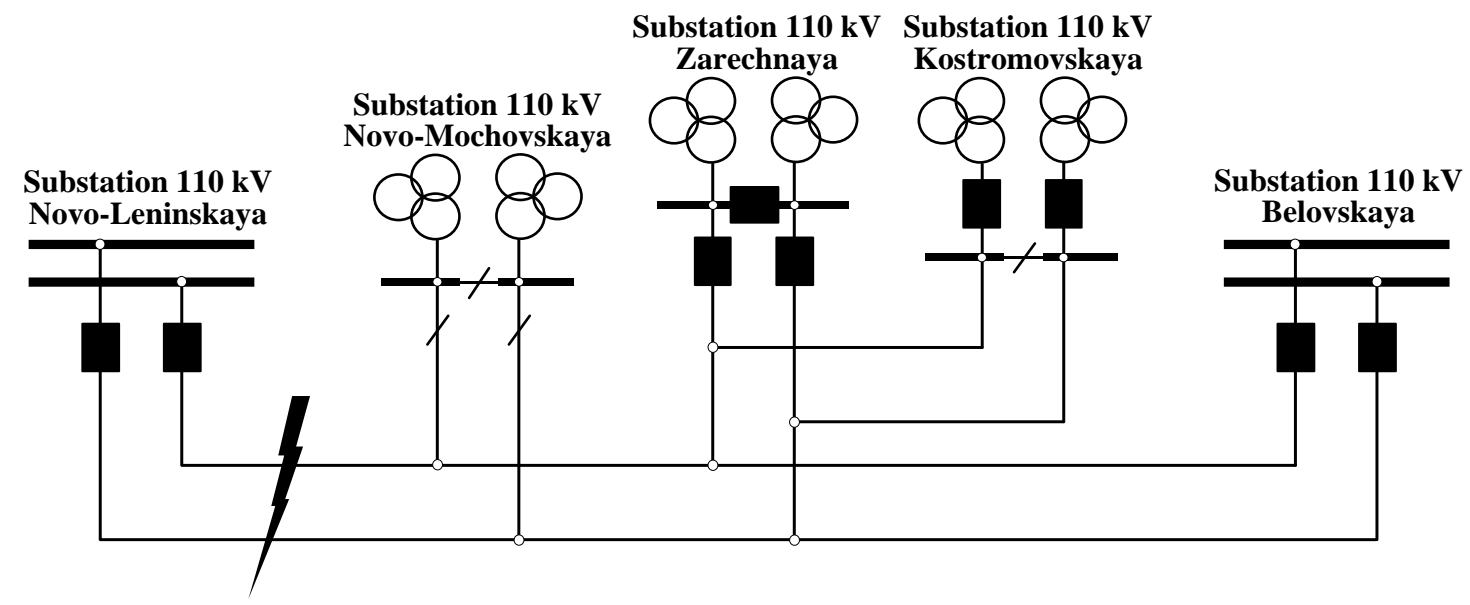

Fig. 4. The circuit of the overhead line $110 \mathrm{kV}$ Belovskaya - Novo-Leninskaya.

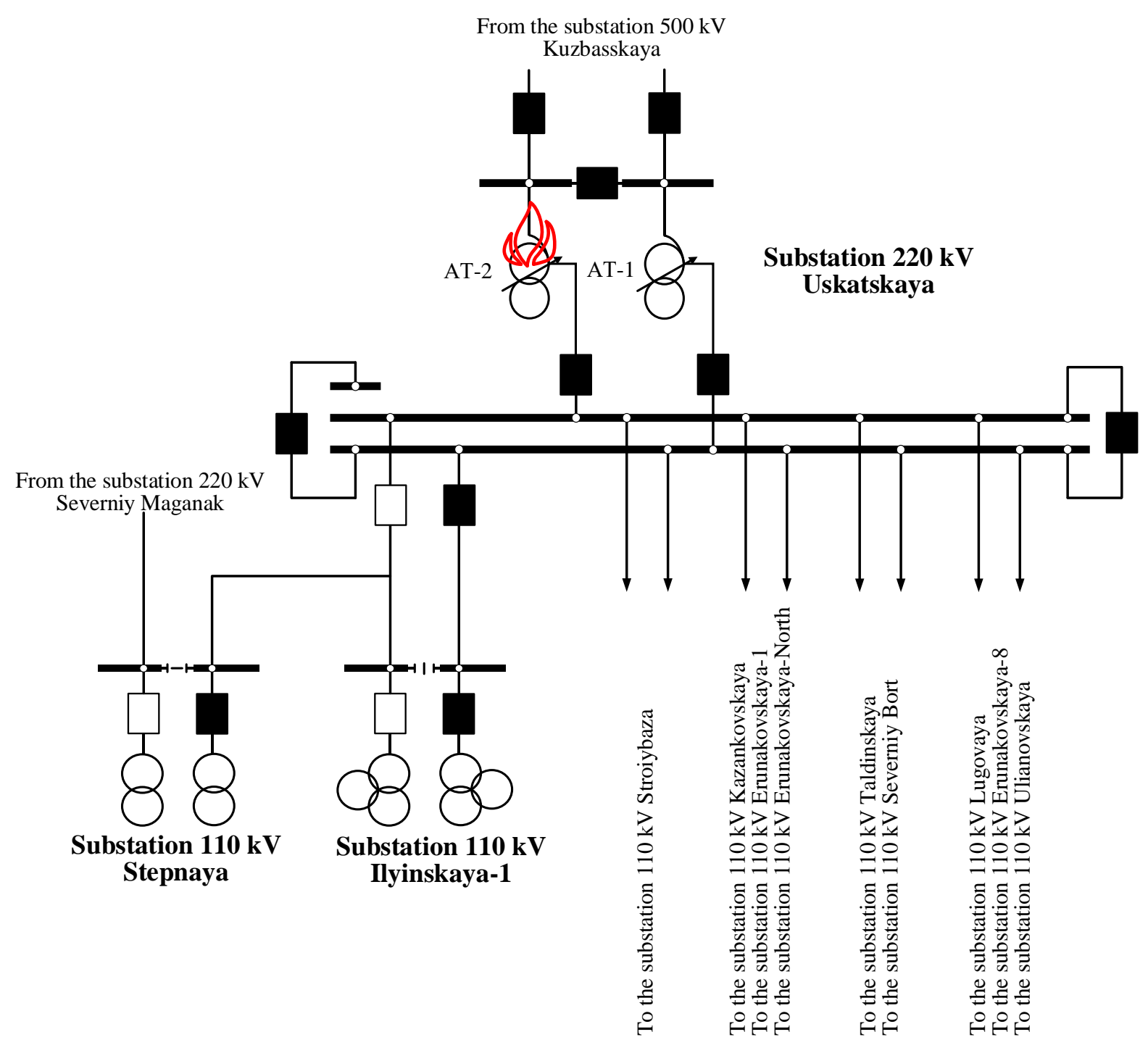

Fig. 5. Post-emergency simplified scheme of the substation $220 \mathrm{kV}$ Uskatskaya. 
Accident elimination lasted for about eleven hours and there were no serious incidents on the de-energized mines.

The owners of the coal enterprises do not always properly realize the danger of this situation. Violations of the external power supply with the total blackouts of the coal mines provoke accidents with possible casualties. The responsibility for these events will be on the owner, due to lack of reserve power supplies for electroreceivers of emergency reservation, the necessity of which is regulated by the normative documents [4-6]. To solve this problem and ensure safe working conditions in coal mines of the Kemerovo region it is necessary to carry out technical audits.

Technical Audit is an independent, comprehensive, documented assessment of compliance with requirements of normative documents and the preparation of recommendations to improve such activities. The main objective of technical audit is to show to the owner of the coal enterprise objective overview of the power supply reliability level and the basic ways of its increase. The final goal is to reduce the probability of total blackouts of the coal mines with shutdown of emergency reservation electroreceivers.

To standardize the procedure of carrying out technical audits and identifying common steps of their implementation the Methodology of technical audit of external power supply networks of coal mines in the Kemerovo region has been developed by the staff of the "Department of electrical supplies of mining and industry enterprises" of KuzSTU.

Technical audit consists of two main steps:

1. Analysis of the actual level of the external power supply reliability of the coal mine.

2. Development of a set of measures aimed at improving the reliability of power supply.

The first step is the analysis of project, executive and operational documentations used in the operation of electrical installations (substations, switchgears, overhead and cable transmission lines), which provide transmission of electrical energy from the power centers to the substation of coal mine. The main purpose of this step is to identify the weak points of the external power supply system of the coal mine and to analyze the possibility of accidents.

In addition, on the first step the audit addresses the elements of the internal power supply system of the coal mine. Analysis of the mine dispatcher control system and verification of proper organization of electricity supply to consumers of special group of the first category of reliability, are performed.

Then, the development of technical solutions is carried out aimed at addressing the existing shortcomings which have been identified on the first step. The proposed technical solutions primarily should be aimed at improving the reliability of the circuit connection of the mines substation to the power system and the organization of reserve electrical supply.

Reserve electrical supply can be provided by selfcontained power supplies (e.g. diesel generator plant) or by a separate power line from power source in power system, which operation mode is independent of the operation of the main power centers of coal mine. The choice of a particular technical solution is performed individually for each of the audited enterprises.

In order to increase interest of the owners of the coal enterprises in technical audit and the implementation of the proposed measures in technical audit, special attention should be paid to the feasibility of the proposed solutions. In the final report, the economic effect from their implementation should be shown in an explicit form. The economic effect of the implementation of measures is based on reducing the value of the expected economic impact of power failure.

\section{CONCLUSION}

The high accident rate of electrical networks of power system of the Kemerovo region and the lack of reserve power supplies threaten with the total blackouts of hazardous production facilities that provoke the appearance of their emergency situations there. To ensure safe working conditions at the coal enterprises of the Kemerovo region it is necessary to carry out technical audit of external power supply networks.

As a result of technical audit of the coal mine, the owner receives objective information about the level of reliability of electricity supply of the mine, the risk of accidents and possible options of their elimination. On the basis of which he may take appropriate measures (the adjustment of the investment program, custom of project work etc.) to implement the proposed measures to improve the reliability of power supply.

\section{REFERENCES}

[1] V.E. Fortov, A.A. Makarov, T.A. Mitrova "Global energy security: Problems and solutions", Herald of the Russian Academy of Sciences, 2007, vol. 77, Issue 1. - P. 7-14.

[2] A.F. D'yakov "Ways to enhance the reliability of power supply in Russia", Herald of the Russian Academy of Sciences, 2012, vol. 82 Issue 2. - P. 90-101.

[3] V.V. Khudyakov "Increasing the reliability of electric networks", Russian Electrical Engineering, - 2011, vol. 82, Issue 9. - P. 455-459.

[4] Decree of the Government of the Russian Federation of 04.05.2012 \#442 "O funktsionirovanii roznichnykh rynkov elektricheskoy energii, polnom i (ili) chastichnom ogranichenii rezhima potrebleniya elektricheskoy energii" (vmeste s "Osnovnymi polozheniyami funktsionirovaniya roznichnykh rynkov elektricheskoy energii", "Pravilami polnogo i (ili) chastichnogo ogranicheniya rezhima potrebleniya elektricheskoy energii") // SPS Konsul'tantPlyus.

[5] Order of the Russian Ministry of Energy of 06.06.2013 \#290 "Ob utverzhdenii Pravil razrabotki i primeneniya grafikov avariynogo ogranicheniya rezhima potrebleniya elektricheskoy energii (moshchnosti) i ispol'zovaniya protivoavariynoy avtomatiki" (Zaregistrirovano v Minyuste Rossii 09.08.2013 \# 29348) // SPS Konsul'tantPlyus.

[6] Decree of the Government of the Russian Federation of 27.12.2004 \#861 "Ob utverzhdenii Pravil nediskriminatsionnogo dostupa k uslugam po peredache elektricheskoy energii i okazaniya etikh uslug, Pravil nediskriminatsionnogo dostupa $\mathrm{k}$ uslugam po operativnodispetcherskomu upravleniyu $\mathrm{v}$ elektroenergetike i okazaniya etikh uslug, Pravil nediskriminatsionnogo dostupa k uslugam administratora torgovoy sistemy optovogo rynka i okazaniya etikh uslug i Pravil tekhnologicheskogo prisoedineniya energoprinimayushchikh ustroystv potrebiteley elektricheskoy energii, ob"ektov po proizvodstvu elektricheskoy energii, a takzhe ob"ektov elektrosetevogo khozyaystva, prinadlezhash-chikh setevym organizatsiyam i inym litsam, k elektricheskim setyam" // SPS Konsul'tantPlyus. 
[7] A.I. Kostogryzov, V.N. Kosterenko, A.N. Timchenko "Osnovy protivoavariynoy ustoychivosti ugol'nykh predpriyatiy [Fundamentals of emergency stability of coal enterprises]". - Moscow: Publishing «Gornoe delo» Ltd «Kimmeriyskiy tsentr», 2014. - 336 p.

[8] Sh.M. Tuguz "Sostoyanie promyshlennoy bezopasnosti na predpriyatiyakh ugol'noy promyshlennosti v 2006 g. [Status of industrial safety in the coal industry in 2006]", Bezopasnost truda v promyshlennosti [Occupational safety in industry], 2007. No 3. - P. 4245.

[9] Metodika opredeleniya avariynoy i tekhnologicheskoy broni elektrosnabzheniya predpriyatiy ugol'noy promyshlennosti [Methods of determining the emergency and technological reservation of power supply in the coal industry]. - Moscow, 1989. - $161 \mathrm{p}$.

[10] L.A. Puchkova, G.G. Pivnyaka "Elektrifikatsiya gornogo proizvodstva [Electrification of mining industry]". - Moscow: Publishing of Moscow State Mining University, 2007. T.1. - 511 p.

[11] A. Savinkin "Elektrosnabzhenie ugol'nykh shakht [Electrical supply of coal mines]", Ugol' Kuzbassa [Kuzbass coal], 2015. No 3. - P. 54.

[12] I.V. Sarychev "Analiz otklyucheniy v elektricheskikh setyakh Kemerovskogo rayona [Analysis of outages in power grids of the Kemerovo region]", Kuzbass State Technical University Bulletin, 2005. No 3. - P. 15-17.

[13] A.G. Zakharova " Ekspluatatsionnaya nadezhnost' statsionarnykh elektricheskikh setey ugol'nykh razrezov Kuzbassa [The operational reliability of stationary electrical networks of Kuzbass coal mines]", Kuzbass State Technical University Bulletin, 2008. No 4. - P. 56-58.
[14] A.G. Zakharova, N.M. Shauleva "Vliyanie konstruktivnykh i tekhnikoekspluatatsionnykh faktorov na nadezhnost' vozdushnykh liniy elektroperedachi ugol'nykh razrezov [Influence of design, technical and operational factors on the reliability of overhead power lines of coal mines]", Kuzbass State Technical University Bulletin, 2010. No 1. - P. 110-113.

[15] V.N. Matveev, K.A. Varnavskiy "K voprosu o nadezhnosti elektrosnabzheniya ugol'nykh shakht Kuzbassa [To the question of reliability of power supply of coal mines in Kuzbass]", Materialy III mezhdunar. nauch.-prakt. konf. Sovremennye tendentsii i innovatsii v nauke i proizvodstve, Mezhdurechensk, 2-4 aprelya 2014 g. [Modern trends and innovations in science and industry: proceedings of the international scientific conference (April, 2-4, 2014)]. Kemerovo, 2014. - P. 62-63.

[16] A.S. Yarosh, O.V. Naumov, D.S. Kudryashov "Nekotorye problemnye voprosy elektrosnabzheniya ugol'nykh predpriyatiy Kuzbassa [Some problematic issues of power supply of Kuzbass coal companies]", Bezopasnost' truda $v$ promyshlennosti [Occupational Safety in Industry], 2014. No 8. - P. 69-71.

[17] D.S. Kudryashov "O nadezhnosti elektrosnabzheniya ugol'nykh predpriyatiy Kuzbassa [On the reliability of power supply of the coal enterprises of Kuzbass]", Materialy I Vseros. nauch.-prakt. konf. Energetika i energosberezhenie: teoriya i praktika, Kemerovo, 3-5 dekabrya 2014 g. [Energy and energy efficiency: Theory and Practice, proceedings of the national scientific conference (December, 3-5, 2014)]. Kemerovo, 2014 